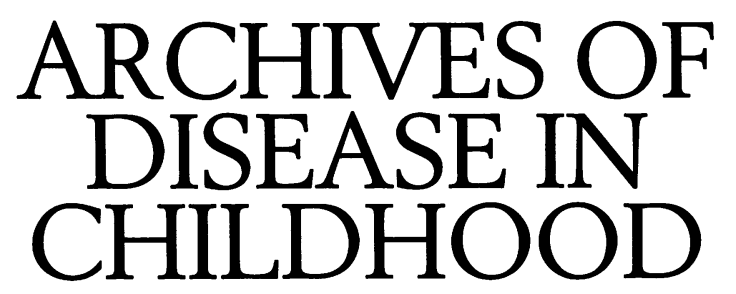

The fournal of the British Paediatric Association

\title{
Professor Sir David Hull
}

The 68th Annual Meeting of the British Paediatric Association (BPA) took place in York in April. During the meeting the President, Professor Roy Meadow, gave the following address before presenting the medal, and a volume of the collective writings of Sir James Spence, to the medallist.

The James Spence Medal is the premier award of our association. It commemorates Sir James Spence, Professor of Child Health in Newcastle, who was one of our founder members in 1928 and BPA President in 1950. The award is made for outstanding contributions to the advancement or clarification of paediatric knowledge; and today's recipient qualifies on both those grounds.

David Hull was born in Blackburn, attended grammar school in Poulton-le-Fylde and, with the customary caution of a Lancastrian, unwilling to cross either the Mersey or the Pennines, he enrolled as a medical student at Liverpool University. After qualification he completed two years' national service in the Royal Army Medical Corps, serving mainly at the British Military Hospital in Berlin. Afterwards he returned to training posts in London.

A critical appointment for him was as Nuffield Research Fellow at the Institute for Medical Research in Oxford. That unit, directed by Geoffrey Dawes, was at the forefront of animal physiological perinatal research, and provided valuable research training for a succession of young doctors who were to become leaders of perinatal medicine in this country and abroad. It was in Oxford that David Hull formed links with other research associates, and developed interests that were at the centre of his research activities for the next three decades. His first paper with Michael Dawkins, published in the Fournal of Physiology in 1963, was entitled 'Brown fat and the response of the newborn rabbit to cold'. Brown fat being an adipose-like

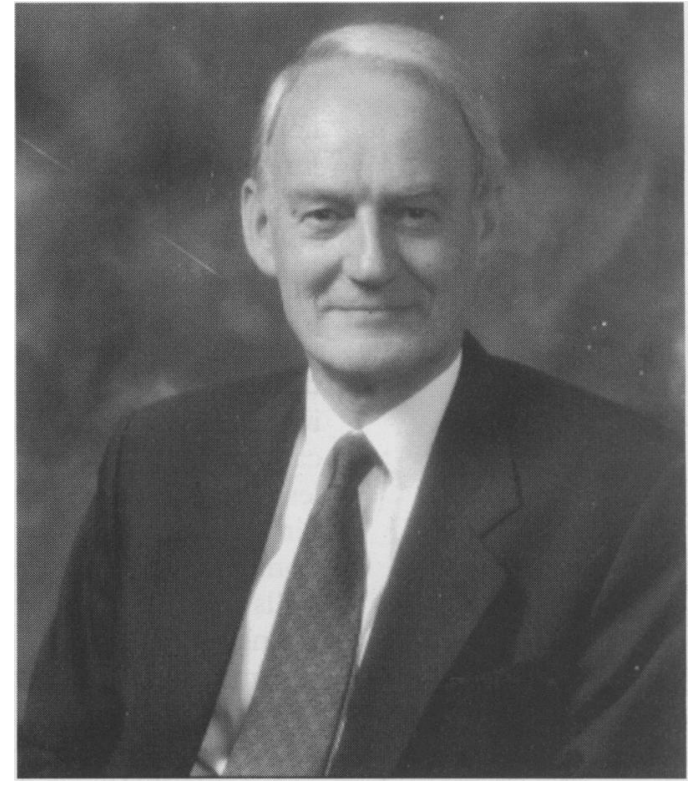

tissue found in hibernating animals and in the human neonate, around the shoulder blades and the kidneys, with the capacity for rapid lipolysis and heat production. Several papers on that subject followed, so much so that in his early years he was referred to as 'brown fat Hull'. It was a particularly inappropriate label for someone with his lean and gracious good looks.

After three years as Lecturer in Paediatrics at Oxford, he was appointed Senior Lecturer, Consultant Physician, and Head of the Respiratory Unit at the Hospital for Sick Children in London, which allowed him to continue his research into fat metabolism and temperature control, and extend it to the respiratory function of young infants. He has continued to lead research projects into these areas throughout his career, and today we recognise those major contributions to the advancement of paediatric knowledge. 
The 1970s were a time when many new academic paediatric departments in Britain were founded. Some of these were in the old medical schools which had not caught up with the fact that paediatrics was one of the central medical disciplines, while others were at the newly established medical schools. The new medical school at Nottingham was fortunate to have David Hull as its foundation Professor of Child Health. He was able to ensure that paediatrics had an appropriate priority in that medical school. He established a firm scientific base for his neonatal and respiratory interests and helped to develop an impressive range of clinical services in Nottingham by attracting other tertiary specialists, and paediatricians willing to develop the equally important community and general services for children.

Together with his colleagues he developed teaching programmes of the highest repute. He is editor and coauthor of a series of excellent textbooks ranging from Essential Paediatrics for the undergraduate, to the postgraduate texts for hospital and community trainees. Never one to pretend that Fowler or any other scholar of the English language would appreciate his prose, nevertheless he has proved himself an excellent author and editor of books because he understands what readers want, and has flair and great skill at presentation. $\mathrm{He}$ is an innovator, and he recognises the need for information to be displayed as well as written.

There will be many, like myself, who when speaking at meetings have been flattered by his rapt attention and the notes that he seems to be writing down. Such people will know also the different feeling when, at the end of the meeting, they discovered on the paper before him a cartoon or caricature of themselves. Nevertheless these are the graphic skills that have placed him in the forefront of producers of educational material. There are moments when these skills need to be put in their place. I recall him taking sabbatical leave to work on a new organisational structure for the BPA, the resultant document was characteristically detailed and well prepared. 'What do you think of it' he asked. It was only after my suggestions about the contents had been somewhat dismissively accepted that I realised that what he really wanted me to say was how much I admired the way he'd used his word processor and his new graphics package to produce an Oscar winning typographical display.

He has used his graphic skills to good effect, to enhance his books. His gifts as a writer, teacher, and educator have been recognised in many countries by the award of lectureships and prizes. In the best spirit of the criteria for the James Spence medallist, he has clarified paediatric knowledge.

David Hull's contributions to paediatrics and child health have been immense. He has been sought by, and contributed to, a host of organisations and working parties concerned with the health of children. After a spell as adviser on paediatrics to the Government Chief Scientist, he served on the Committee of Safety of Medicine and, for the last 10 years, he has been adviser on paediatric medicine to the
Chief Medical Officer. At a national level he represents paediatricians effectively and stands up for the rights of children. His background and his skills enable him to do so in a manner that is effective, yet not too confrontational, so that the strongest proposal or the biggest change merely appears as common sense when presented by him. Just as it was obvious that the new medical school in Nottingham would embrace paediatrics as a major discipline, and have child health as one of it's first academic departments, so the BPA becoming a college was, for David Hull, not a time consuming crusade, but an inevitable event which he strongly supported because, since all major disciplines in the UK were represented by a college and needed that title to do their work effectively, so the BPA had to become a college. Others envied the clarity with which he saw the future and the confidence with which he led our association towards its crucial decisions, and to the creation of a draft Charter for a College of Paediatrics and Child Health.

He has been President of many organisations, including four years as President of the Neonatal Society. However, most of us will remember him best and with the greatest gratitude for his contributions to the BPA. He had a long period of service for the Academic Board, and was its Chairman from 1978-81. Ten years later he was elected our President and ensured that the BPA had a management and organisational structure to deal effectively with the academic, health service, and research tasks of our new college.

$\mathrm{He}$ is a strong contributor on all committees because he sees the nub of a problem and can state unpleasant truths with a clarity and charm that both persuades and disarms, and his sense of fun makes everyone happier. $\mathrm{He}$ has charisma and attracts others to work effectively with him. He leads from the front, and we have been privileged to follow.

Recognising that, as they would say in Lancashire, he is still 'nobut a lad', we are glad that he continues with so many of his important roles for British paediatrics, and particularly glad that he is leading forward our own Medicines' Committee to be responsible for a National Formulary for Children.

His new title, with his appointment as Knights Bachelor in 1993, delighted all paediatricians. Despite the title 'Knights Bachelor', it is particularly pleasing that the wives of such non-bachelors, receive a title also. None could be more deserving than Carol, Lady Hull, who has been not only the best friend for David, but also for the BPA during his life as a paediatrician. We thank her for the thoughtfulness, grace, and happiness which she has brought to so many paediatric occasions. And we are glad that she is here today so that we may celebrate them as a pair, or rather since they have three children (one of whom is a paediatric senior registrar), as a family. Congratulations.

David Hull will carry on contributing to paediatrics and receiving more honours. However it is at this stage that we, the British Paediatric Association, are determined to honour 
him. It is with pride and happiness that I now present you, Professor Sir David Hull, with the 1996 James Spence Medal.

\author{
James Spence Medallists \\ 1960 Professor A A Moncrieff \\ 1961 Professor R A McCance \\ 1962 Sir F Macfarlane Burnet \\ 1964 Professor L S Penrose \\ 1965 Dr Cicely D Williams \\ 1967 Professor R R A Coombs \\ 1968 Dr Mary D Sheridan \\ Dr D W Winnicott \\ 1969 Dr G S Dawes \\ 1970 Professor D V Hubble \\ 1971 Dr W W Payne \\ 1972 Dr R C MacKeith \\ 1973 Professor C A Clarke \\ 1974 Dr J Bowlby \\ 1976 Dr D M T Gairdner
}

1977 Professor R S Illingworth 1978 Professor S D M Court 1979 Professor K W Cross 1980 Professor J M Tanner 1981 Dr Elsie M Widdowson 1982 Dr D MacCarthy 1983 Professor J O Forfar 1984 Dr J W B Douglas 1985 Dr N S Gordon 1986 Sir Peter Tizard 1987 Professor J L Emery Dr F J Miller 1988 Professor O H Wolff 1989 Professor D C Morley 1990 Professor L B Strang 1991 Professor John A Davis 1992 Professor Richard W Smithells 1993 Professor Dame June Lloyd 1994 Professor E O R Reynolds 1995 Professor Richard H R White 